\title{
The role of railway transport in designing a proecological transport system
}

\author{
J. Żak ${ }^{1}$, I. Jacyna-Gołda ${ }^{2}$, A. Merkisz-Guranowska ${ }^{3}$, K. Lewczuk ${ }^{1}$, \\ M. Kłodawski ${ }^{1}$, D. Pyza ${ }^{1}$, E. Szczepański ${ }^{1} \&$ M. Wasiak ${ }^{1}$ \\ ${ }^{1}$ Faculty of Transport, Warsaw University of Technology, Poland \\ ${ }^{2}$ Faculty of Production Engineering, \\ Warsaw University of Technology, Poland \\ ${ }^{3}$ Faculty of Machines and Transport, \\ Poznan University of Technology, Poland
}

\begin{abstract}
This paper is prepared as a part of the scientific project "Proecological transport system designing" (EMITRANSYS). It presents the selected aspects and roles of railway transport in realization of the tasks set out by the national transport system. Particular attention is paid to the ecological aspects of railway transport, especially to the emission of pollutants in comparison to road transport. The ecological aspects are crucial for a systemic approach to the designing of transport and are important in developing a sustainable economy. One of the criteria for designing a large scale transport system is the external cost of environmental degradation. Two partial criteria considering external costs related to harmful emissions resulting from cargo and passenger streams distribution onto a network are discussed in the paper. These criteria are implemented into the PTV Visum environment for simulation experiments.
\end{abstract}

Keywords: railway transport, ecology, transport system, external costs.

\section{Introduction}

Increasingly, research on the development of economy, besides the primary goal of lowering costs and increasing efficiency, must take into account overriding objective which is protecting natural environment for next generations. To achieve that societies should communicate and take right decisions for proper functioning 
of systems influencing quality of life like system of global climate monitoring. Therefore, in all decision situations concerning from one hand large scale transport projects, and everyday operation from the other hand, decision makers must look for compromise between environmental, economic, and social issues to fulfil definition of sustainable development.

The transport is one of the most environmentally destructive branches of economy except of some types of heavy industry or agriculture. It is estimated that transport is responsible for about $25 \%$ of global emission of greenhouse gases related to human activities. The situation can be improved by organizing transport systems with regard to the rules of sustainable development, wherein this development should not only focus on minimization of emission, but represent aware activities to protect natural environment.

Transport is only sector of economy in UE in which emission of greenhouse gases consequently increases since 1990, contributing to climate change, high congestion, accidents, air pollution, and noxious noise. Between 1990 and 2005 emission of greenhouse gases related to national transport in UE-15 countries increased by $26 \%$. About $90 \%$ of that amount was produced by road transport.

One of the major trends in sustainable development pointed by OECD and UE is acquisition of passenger streams by environmentally friendly modes of transport, mainly by rail transport. Ecological and energetic advantages of railways give potential competitive advantage on transport market, but unfortunately at the moment there is no real possibility of taking over the part of the road transport by railway. It is because particular users decide about usefulness of transport service, which is primarily perceived by time of realization, price, comfort conditions, and reliability of service [1].

European Union provides plenty of regulations allowing modernization of transport to make it less harmful for environment. The White Paper of European Commission (2001) presents a plan of creating unified European transport area to gain competitive and resource efficient transport system [2]. One of brought up issues are ways of achieving proecological transport system which in 2050 reduces emission of carbon dioxide by $60 \%$. This is one of the UE Transport Policy objectives, that will be realized by shifting long and average distance passenger travel from road transport to other modes (especially rail), and lowering external costs associated with road accidents.

Another document regulating proecological tends in transport systems is Green Paper of UE (2007) about mobility in urban areas [3]. In 2008 European Commission presented a Communication about internalization of external costs of transport [4]. Internalization is the element contributing to sustainable development. Because external costs are bear not only by transport users but society together, Commission invite users to changes in behaviour that could translate into lowering external costs.

Summing up, according to experts of the European Commission sustainable development:

- ensures safe access to communication, not endangering human health and environment in equal manner to the current and next generation, 
- allows effective operation with access to different means of transport to support economy and regional development,

- reduces emission and wastes that could be absorbed by grounds, uses renewable resources in amounts that could be recreated, uses non-renewable resources in amounts that could be replaced by renewable substitutes with minimal land consumption and noise.

Considering above passenger rail transport as public by definition is in line with ideas of sustainable transport and therefore environmentally friendly. According to environmental parameters also the freight railway transport is listed as environmentally friendly.

\section{Railway transport as an element of transport system}

Starting from the definition of the system it can be stated that transport system is a set of elements organizationally connected in a way ensuring effective realization of passenger and freight movement in transport network with regard to minimization of total costs, including social costs [5].

In this context it is assumed that:

a) Transport system (ST) aims in realization of transport tasks (passenger and freight transport) with particular attention paid to minimal emission of harmful compounds by means of transport: $\mathbf{S T}=\langle\boldsymbol{A}, \boldsymbol{R}\rangle$, where $\boldsymbol{A}$ - set of elements of $\mathbf{S T}, \boldsymbol{R}$ - set of relations in $\mathbf{S T}$,

b) ST embraces whole economy and the whole country,

c) ST is a servicing system for other areas of economy (mining, production, etc.) and performs transport tasks resulting from demand for passenger and freight transport.

Passenger and cargo flows in national transit port system are performed by different means of transport. It means that increase of efficiency of national transport system while minimizing harmful exhaust emissions can be achieved mainly through the rational use of transport infrastructure. Parameters of transport infrastructure like its distribution, and density in geographical areas, technical and maintenance condition influence possibility of movement and capacity, cost, quality and time of travel.

Transport system can be divided into sub-systems representing modal share. In Poland two of them dominate: railway transport system STKP, and road transport system STDP, and $\mathbf{S T}=\mathbf{S T K P} \cup \mathbf{S T D P}$.

The objects of railway transport STKP system are:

- central control and planning,

- railway infrastructure,

- carriers,

- the regulator of railway market (in Poland: Office of Rail Transport),

- users, clients. 


\section{The share of railway transport in flow volumes}

Railway transport can't stand the competition for land freight transport with road transport, especially in category of smallwares. In recent years the decrease of transport volumes in Poland is observed. Figure 1 presents the share of particular means of freight transport in external costs in Europe. Figure 2 presents market share of each mode of transport according to mass of transported goods in Poland in 2011 .

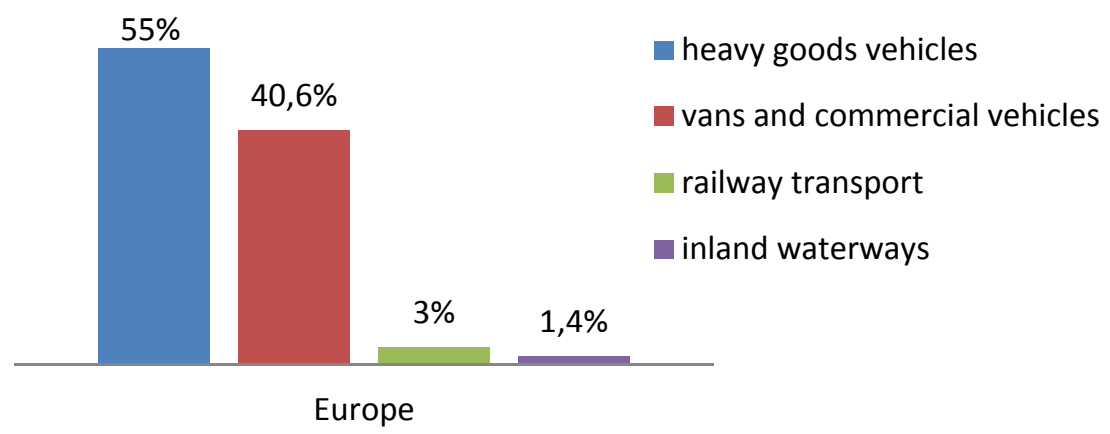

Figure 1: The share of particular modes of freight transport in external costs in Europe. Source: work based on [1].

83.8

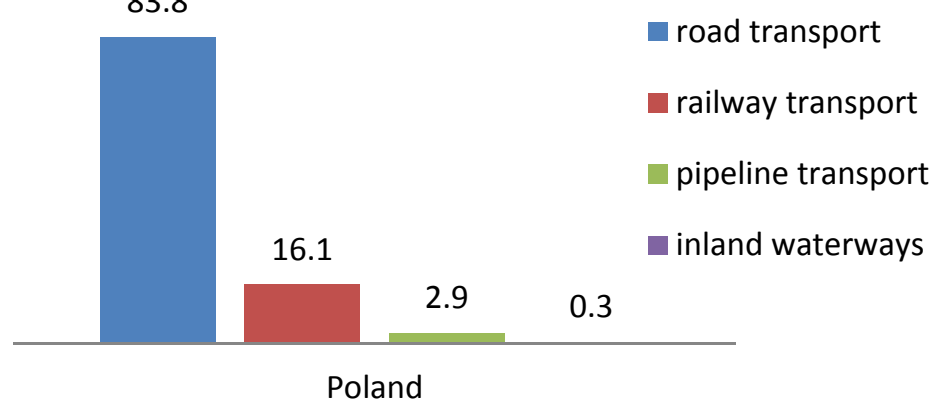

Figure 2: Market share of each mode of transport according to mass of transported goods in Poland in 2011. Source: work based on [1].

As for passenger transport the role of railway is negligible (5.2\% of passenger flows). Smaller share of rail transport that Poland is noted in only few EU countries, usually smaller in terms of population and area. In most countries, rail transport is steadily rising (although developed network of highways). Figure 3 shows the dynamics of change of in number of passengers conveyed by railway transport system in the years 1997-2012. 


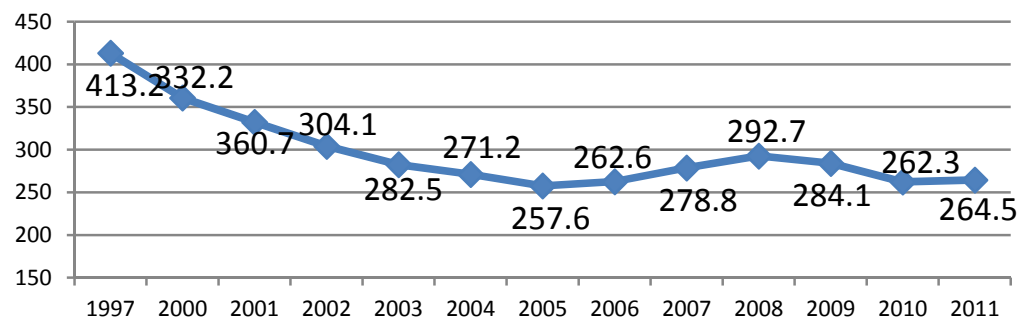

Figure 3: Number of passengers carried by railway transport in 1997-2011 (millions of passengers). Source: work based on [1].

In recent years railway transport partially acquires passenger flows from bus communication, especially on regional level.

\section{Emissivity of railway transport and road transport: comparative analysis}

External costs connected to transport result mostly from air pollution, emission of $\mathrm{CO}_{2}$, noise, traffic congestion, degradation of infrastructure and buildings, terrain insulation by line infrastructure, and hazard to animals. The external costs are highest for air and road transport.

At the same time the EU Directives imply the reduction of harmful emissions by $80-95 \%$ until 2050 (in comparison with 1990). While referring directly to the restrictions imposed on the transport sector, greenhouse gases emissions are to be reduced by $20 \%$ until 2030 (in comparison with 2008).

Road transport is a main source of air pollution threatening natural environment, health, an even human life. Using fossil fuels to power vehicles generates air pollutants like: carbon monoxide, nitrogen oxides, hydrocarbons (including polycyclic aromatic hydrocarbons), particulate matter, and heavy metals. According to Central Statistical Office, in the whole country road transport is responsible for more than $28 \%$ of total emission of nitrogen oxides, more than $27 \%$ of carbon monoxide emissions, and over $15 \%$ of dust matter. In large urban areas, especially with well-developed and heavy loaded by traffic centre, the share of road transport and public communication in emission is much larger, reaching in central districts up to $90 \%$. Statistics for European Union are: $39 \% \mathrm{NO}_{\mathrm{x}}$, almost $36 \%$ of CO, $17 \%$ of non-methane volatile organic compounds (NMVOCs), more than $17 \%$ of PM2,5 and almost 15\% PM10 came from transport. All other modes of transport have significantly smaller proportion of such emissions.

On the other hand railway is considered generally as less harmful to the environment than other modes of land transport [6-8]. It also generates organic and inorganic pollution [9-13] resulting mainly from utilizing oils and coolants, using petroleum, metal ores, fertilizers and other chemicals. According to [14], [15], and [10] railway areas are considered to be places of high emission of heavy metals. The impact of rail transport on the environment is mostly the noise and vibration (from locomotives), specific types of pollution, emission of dust, land 
consumption, and partitioning natural environment. Harmful emission from railway transport in European Union is of the 1 to $3 \%$ of total emission $[17,18]$. European Environment Agency reports that railway transport in EU is responsible for $1.2 \%$ of total emission of $\mathrm{NO}_{\mathrm{x}}$ and $0.13 \%$ of NMVOCs (EEA 2012, [19]). Depending on the EU-member total national $\mathrm{NO}_{\mathrm{x}}$ emission varies between $0.3 \%$ to $7.2 \%$ (more than $1 \%$ in Poland), and total NMVOCs emission varies between $0.04 \%$ to $0.93 \%(0.24 \%$ in Poland $)$.

Concluding, the impact of railway transport on the environment and traveling safety is incomparably less than in road transport. At the same time the European Union railways carry $6.1 \%$ of the total passenger flows and $10.7 \%$ of freight transport (17.1\% in the inter-Union movement [20]).

\section{Transport tasks acquisition by railway under external costs including an example}

To reduce external costs of transport a significant disproportion between cargo and passenger volumes handled by road and rail transport must be changed.

In the context of external costs generated by transport it can be assumed that train in Poland is able to convey 29 of $40 \mathrm{ft}$. containers with a gross weight of 25 tonnes. Office of Rail Transport [1] estimates the average distance in intermodal transport for about 415 kilometres in 2011. Thus, the rail freight transport performance (equivalent to the work done by road) was about 300875 tonne-km. According to "External Costs of Transport in Europe (Update Study for 2008)", the average external costs generated by freight trains in Poland were 10.4 euro/1000 tonne-km. The same report states that external costs associated with performing 1000 tonne-km by heavy road transport in Poland are 33.5 euro/1000 tonne-km.

To study the impact of external costs for the freight volumes distribution into a transport network, the model of Polish transport system was developed in PTV Visum. At this moment model doesn't include fully passenger transport. It maps all major road and railway connections, and nodal points where material streams appear, disappear and are redirected within a network (figure 4).

An innovative approach to this problem is to develop computer application of large scale transport system in PTV Visum to model inter-modal interactions, and take into account different external costs at the global level.

Selected nodes of network can change mode of transport and the mean of transport (vehicle). Edges of network are fully parameterized by proper characteristics (i.e. category or class of road or railway, number of lines or rails in particular direction, lengths and dimensions of sections, maximal and daily capacities, average velocity, speed limits, gauges and other). Technical aspects of model implementation are presented in [21]. Transport connections are divided into categories and classes defined by individual characteristics and technical parameters necessary to perform traffic distribution and to estimate harmful emissions. 

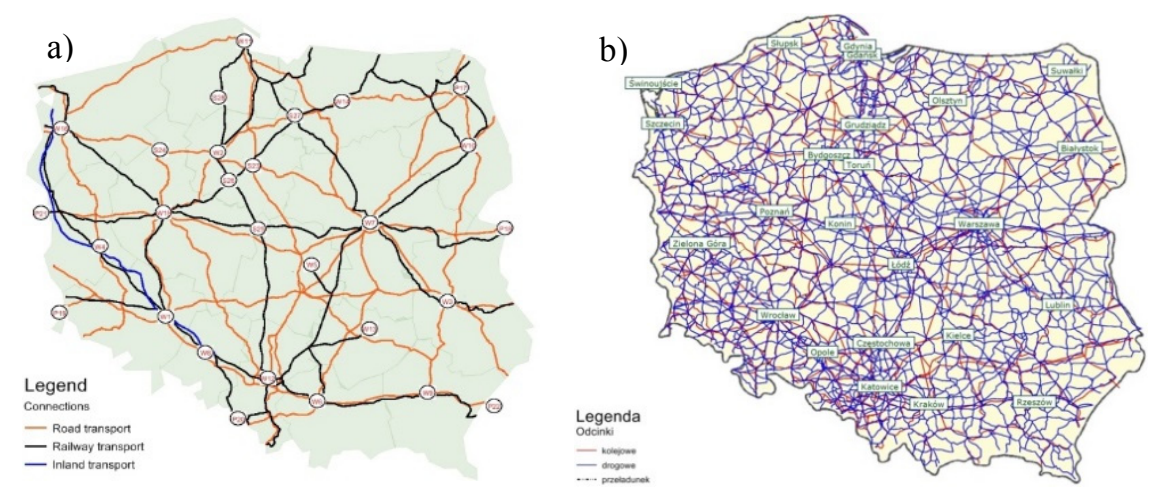

Figure 4: Transportation system of Poland in PTV Visum; a) main transport connections, b) detailed transport network.

The first stage of research was consisted of distributing freight volumes into bimodal transport network (road and rail) without taking into account external costs of transport. Second variant was including average external costs of $0.01 € / 1$ tonne-km for railway transport and $0.033 € / 1$ tonne-km for road transport.

In a first option external costs of transport are not included to the total operation cost, so global criteria function minimizing total costs for first option takes form:

$$
\sum_{s t \in \boldsymbol{S} \boldsymbol{T}} \sum_{\left(i, i^{\prime}\right) \in \boldsymbol{L} \boldsymbol{E}} \sum_{k \in \boldsymbol{K}} \sum_{(a, b) \in \boldsymbol{E}} x\left(s t, i, i^{\prime}, k\right) d\left(i, i^{\prime}\right) q\left(i, i^{\prime}, s t, k\right) k(s t) \longrightarrow \min
$$

In a second option freight volumes distribution is done in view of total costs including external costs of transport $k z(s t)$. The criteria function is then:

$$
\sum_{s t \in \boldsymbol{S} \boldsymbol{T}} \sum_{\left(i, i^{\prime}\right) \in \boldsymbol{L} \boldsymbol{E}} \sum_{k \in \boldsymbol{K}} \sum_{(a, b) \in \boldsymbol{E}} x\left(s t, i, i^{\prime}, k\right) d\left(i, i^{\prime}\right) q\left(i, i^{\prime}, s t, k\right)(k(s t)+k z(s t)) \longrightarrow \min
$$

where:

$$
\begin{array}{lll}
k & - & \text { mode of transport (railway, road), } \\
k(s t) & - & \text { cost of } 1 \text { tonne-km of using vehicle of } s t \text {-th type, } \\
k z(s t) & - & \text { unit external costs for } s t \text {-type of vehicle, } \\
d\left(i, i^{\prime}\right) & - & \text { distance between nodes } i \text { and } i^{\prime} \\
x\left(s t, i^{\prime}, i^{\prime}, k\right)- & \text { assignment of } s t \text {-th type of vehicle of } k \text {-th mode to perform } \\
& \text { tasks on transport link }\left(i, i^{\prime}\right), \\
q\left(i, i^{\prime}, s t, k\right)- & \text { flow volume on transport link }\left(i, i^{\prime}\right) \text { performed by } s t \text {-th type of } \\
& \text { vehicle of } k \text {-th mode of transport. }
\end{array}
$$

Volume distribution for first variant revealed that road transport was used to perform about $66 \%$ of all tasks (tonne-kms), while the railway transport was engaged to about $34 \%$ of tasks. 
The second stage of research was taking into account external costs as defined above. On the base of distribution of freight volumes on transport network total daily costs of transport were estimated. Including external costs for different types of vehicles caused increase of total cost. The share of railway transport in total transport work increased to about $68 \%$ in relation to road transport. Figures 5 and 6 present distribution of cargo volumes on transport network with, and without, inclusion of external costs.

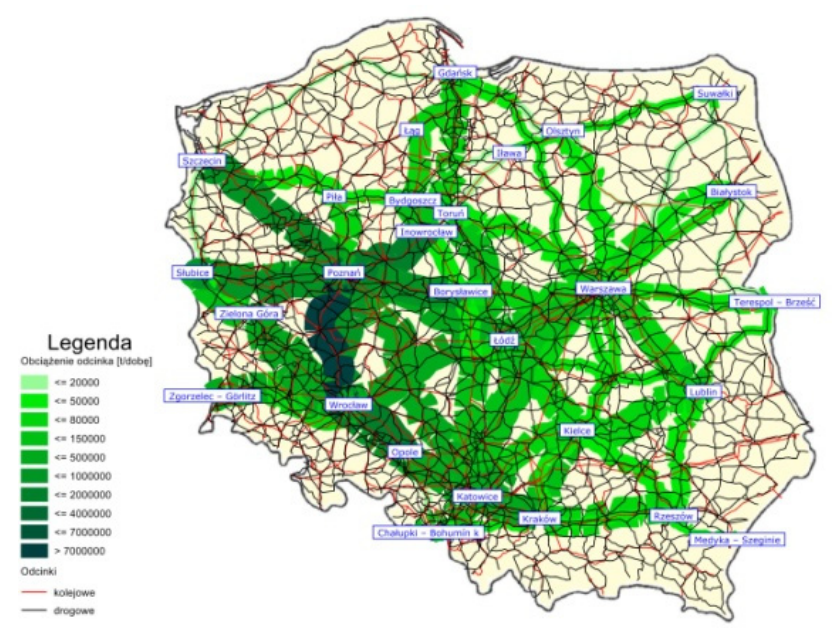

Figure 5: Distribution of freight volumes without taking into account external costs in PTV Visum.

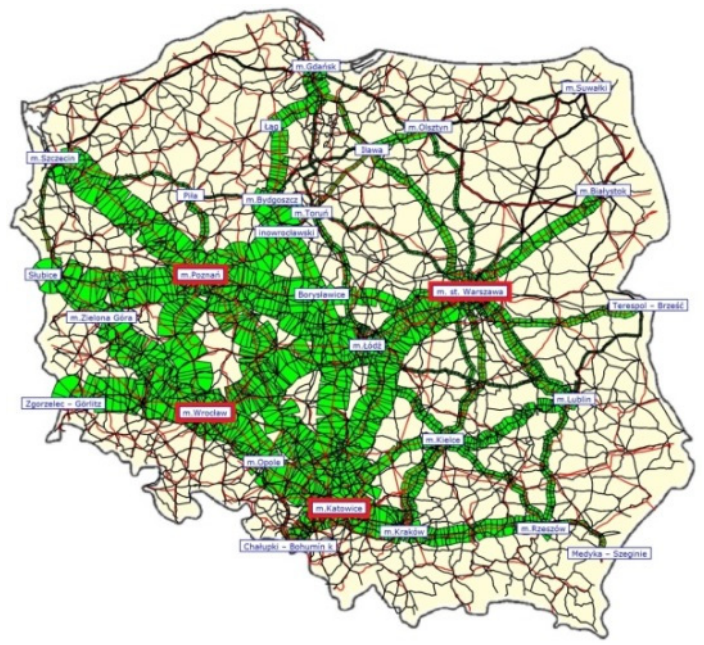

Figure 6: Distribution of freight volumes with taking into account external costs in PTV Visum. 
Annual loadings from freight flows (in tonnes) on particular segments of TEN$\mathrm{T}$ network with external costs of transport in Poland included, for 2011 are presented on figure 7a. Figure $7 \mathrm{~b}$ presents forecasted for Poland 2020 annual loadings of TEN-T network from freight transport with external costs included.
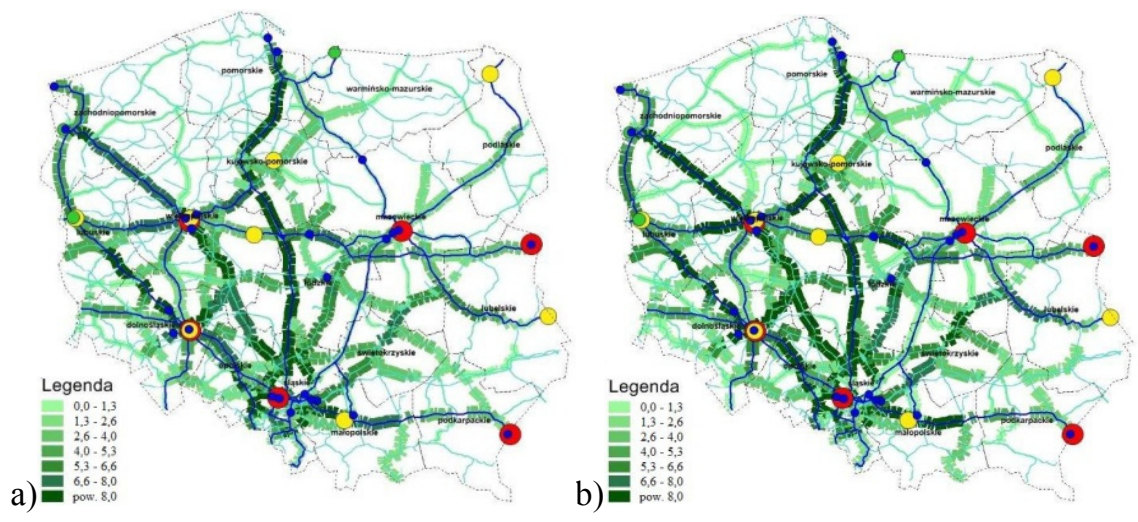

Figure 7: Annual loadings from freight transport on major segments of TEN-T (especially railways) in thousands of tonnes: a) year 2011, b) forecasts for 2020 .

\section{Conclusions}

The share of railway transport in emission of harmful compounds, dust, and other noxious agents is perceptible, but much less than in road transport. Undertaken simulation research on multi-variant freight volume distribution into road and rail modes show that including external costs increases significantly the share of rail transport. The opposite situation is when external costs are not taken as a criterion and then road transport is preferred (Figure 7).

Reliable analysis of the modal split should take into account the influence of particular modes of transport and types of vehicles to environmental degradation. As it is results from the research rail transport is less harmful for natural environment and should be considered as an alternative for road transport.

\section{Acknowledgement}

The scientific research is carried out under the project "Proecological transport system designing" (EMITRANSYS) funded by the National Centre for Research and Development. 


\section{References}

[1] Larsson S.: Revitalising the rail mode. Rail International, 1997, nr 9, 10.

[2] Komisja Europejska: Biała Księga. Plan utworzenia jednolitego europejskiego obszaru transportu - dążenie do osiągnięcia konkurencyjnego i zasobooszczędnego systemu transportu [on-line].

[3] Komisja Wspólnot Europejskich: Zielona Księga. W kierunku nowej kultury mobilności w mieście [on-line]. [Access Mar. 2013.]

[4] Komisja Wspólnot Europejskich: Komunikat Komisji do Rady, Parlamentu Europejskiego, Europejskiego Komitetu Ekonomiczno-Społecznego i Komitetu Regionów. Logistyka transportu towarowego w Europie - klucz do zrównoważonej mobilności [on-line].

[5] Jacyna, M., Modelowanie i ocena systemów transportowych, Warsaw 2009.

[6] European Environment Agency, "Transport and environment: facing a dilemma - TERM 2005: indicators cracking transport and environment in the European Union", ISBN 92-9167-811-2.

[7] Joumard, R., Transport and air pollution 1994 - some conclusions, The Science of the Total Environment, Vol. 169, pp. 1-5, Elsevier 1995.

[8] Schoemaker, Theo J. H. and Peter A. Bouman (1991), "Facts and Figures on Environmental Effects of The Voice of European Railways", Rail Transport and Environment. Facts \& Figures, 2008.

[9] Lacey, R. F., \& Cole, J. A. (2003). Estimating water pollution risks arising from road and railway accidents. Quarterly Journal of Engineering Geology and Hydrogeology, 36(2), 185-192.

[10] Liu, H., Chen, L. P., Ai, Y. W., Yang, X., Yu, Y. H., \& Zuo, Y. B. (2009). Heavy metal contamination in soil alongside mountain railway in Sichuan, China. Environmental Monitoring and Assessment, 152, 25-33.

[11] Malawska M., Wilkomirski B (2001) stopa Akumulacja polichlorowanych bifenyli (PCB) un mniszek lekarski (Taraxacum officinale), w warunkach zanieczyszczenia gleby olejem deliverates Roczn. PZH, nr 4, 295-311.

[12] Malawska M., Wiłkomirski B. (2000) - zanieczyszczenie gleb i roślin metalami ciężkimi w rejonie starego węzła kolejowego w Tarnowskich Górach, w pobliżu dwóch linii kolejowych - Roczn. PZH, 51(3), 259-267.

[13] Malawska M., Wiłkomirski B. (2001) - analiza gleby i roślin (Taraxacum officinale) zanieczyszczenia metalami ciężkimi i wielopierścieniowych węglowodorów aromatycznych (WWA) w rejonie węzła kolejowego Iława Głównej - wody, powietrza i gleby.

[14] Bukowiecki, N., Gehrig, R., Hill, M., Lienemann, B., Zwicky, C. N., Buchmann, B., et al. (2007). Iron, manganese and copper emitted by cargo and passenger trains in Zurich (Switzerland): Size-segregated mass concentrations in ambient air. Atmospheric Environment, 41, 878-889.

[15] Chillrud, S. N., Grass, D., Ross, J. M., Coulibaly, D., Slavkovich, V., Epstein, D., et al. (2005). Steel dust in the New York City subway system as a source of manganese, chromium and iron exposures for transit workers. Journal of Urban Health, 82, 33-42. 
[16] Danklefsen, N., (red), Obliczanie kosztów zewnętrznych w sektorze transportu, Brussels 2009.

[17] Uherek, E., Halenka, T., Borken-Kleefeld, et al.: Transport Impacts on Atmosphere and Climate: Land Transport; Atmospheric Environment (2010), doi: 10.1016/j.atmosenv. 2010.01.002.

[18] Lewczuk K., Żak J., Pyza D., Jacyna-Gołda I., Vehicle routing in urban area - environmental and technological determinants, Urban Transport XIX, Ed. C. A. Brebbia (WIT Transactions on The Built Environment, Vol. 130), str. 373-384. DOI: 10.2495/UT130291 WIT Press Southampton, Boston 2013.

[19] European Environment Agency, Air quality in Europe - 2012 report, Copenhagen 2012.

[20] EU Energy and Transport in Figures; 2009.

[21] Jachimowski R., Kłodawski M., Lewczuk K., Szczepański E., Wasiak M., Implementation of the model of proecological transport system, Journal of KONES Powertrain and Transport, Institute of Aviation (Aeronautics) BK, Vol. 20, No. 4, Warsaw 2013, pp. 129-139.

[22] Environmentally Friendly Vehicle (EFV), Draft Feasibility Statement, Working paper No. EFV-02-03-Rev. 2, 08. 01. 2009.

[23] European Transport Policy for 2020: Time to Decide. Office for Official Publications of the European Communities. Luxembourg, Commission of the European Communities 2001.

[24] Kürer, R. (1993), "Environment, Global and Local Effects" in ECMT (1993).

[25] United States Environmental Protection Agency "The History of Reducing Tailpipe Emissions", May 1999.

[26] World Health Organization, Air quality guidelines for Europe, 2nd ed., Copenhagen 2000.

[27] Bariery rozwoju rynku przewozów - rozwiązania i wymierne korzyści intermodalnych UTK 2013. 